\title{
Btrl genes and the evolution of wheat and Aegilops species
}

Valeriya Vavilova

ICG SB RAS, Novosibirsk, Russia

valeriya-vavilova@bionet.nsc.ru

\author{
Irina Konopatskaia \\ ICG SB RAS, Novosibirsk, Russia \\ sormacheva@bionet.nsc.ru \\ Nikolay P. Goncharov \\ ICG SB RAS, Novosibirsk, Russia \\ gonch@bionet.nsc.ru
}

\author{
Alexandr Blinov \\ ICG SB RAS, Novosibirsk, Russia \\ blinov@bionet.nsc.ru
}

\begin{abstract}
Non-brittle rachis 1 (Btr1) gene involves in regulation of the brittle/ non-brittle spike trait, which is one of the key domestication traits in Triticum species. In this study genetic variability of Btrl genes from di- and tetraploid wheat species and Aegilops speltoides, which is donor of $\mathrm{B}$-genome for polyploid wheat species, were investigated.
\end{abstract}

Keywords - Triticum, Aegilops, spike morphology, brittle rachis, Btrl gene

\section{Motivation and aim}

\section{Motivation}

The Non-brittle rachis 1 (Btr 1$)$ and Non-brittle rachis 2 (Btr2) genes are known to control important agriculture trait in barley, namely the formation of a non-brittle rachis [1]. Homologues genes Brt1 and Btr2 were recently described for wheat species $[2,3]$. It was shown that one non-synonymous substitution in the coding region of Btrl-A gene (A119T) leads to non-brittle rachis formation in accessions of diploid einkorn wheat Triticum monococcum $[2,4]$. The investigation of $B \operatorname{tr} 1-A$ gene variability in polyploid wheat revealed allele which possess the loos-of-function deletion $2 \mathrm{bp}$ in length within the coding region $[3,4]$. All poliploid wheat species studied so far possess the above mentioned deletion in Btrl-A.

Aim

In the present study we investigated genetic variability of Btrl genes from di- and tetraploid wheat species and Aegilops speltoides, which is B-genome donor of polyploid wheats, in order to clarify the phylogenetic relationships between Triticum and Aegilops genera.

\section{Methods}

Germplasm of di- and tetraploid wheat species and Ae. speltoides were grown under standard greenhouse conditions. Brittle/ non-brittle spike trait was determined visually. List of wheat accessions analyzed in this study is presented in Table I. Total DNA was isolated from $100 \mathrm{mg}$ of leaves using the Wizard $\AA$ Genomic DNA Purification Kit (Promega) according to the manufacturer's protocol. The whole genome sequences (WGS) of Triticum dicoccoides (LSYQ02000006), Triticum aestivum (OETA01178479) (B-genome) were used to design genome-specific primers to amplify Btrl-B and $B \operatorname{tr} 1-S$ genes from tetraploid wheats and Ae. speltoides. The primer pair Btr1-BF/ Btrl-BR 5'GACGAGCTTGACCTCCCATGAG $\quad-3 \%$ 5'GTGCGAATCGCTACTCCATC -3' amplified partial upstream and downstream parts and coding region $B \operatorname{tr} 1-B$ and $B \operatorname{trl}-S$ genes. For PCR amplification of the same Btrl-A region primers Btr-A1-F/ Btr-A1-R were used [5]. PCR was performed in $20 \mu \mathrm{l}$ volume containing $20 \mathrm{ng}$ of genomic DNA,
$10 \mathrm{mM}$ Tris- $\mathrm{HCl}$ (pH 8.9), $1 \mathrm{mM}\left(\mathrm{NH}_{4}\right)_{2} \mathrm{SO}_{4}, 1.5 \mathrm{mM} \mathrm{MgCl}_{2}$, $200 \mu \mathrm{M}$ dNTPs, $0.5 \mu \mathrm{M}$ primers, and $0.25 \mathrm{U}$ of Taq DNA polymerase. PCR products were separated by agarose gel electrophoresis and purified using a QIAquick Gel Extraction Kit (QIAGEN). For all wheat accessions purified PCR products were sequenced. Sequencing reactions were performed with $20 \mathrm{ng}$ of the PCR product and ABI BigDye Terminator Kit on an ABI 3130XL Genetic Analyser (Applied Biosystems) in SB RAS Genomics Core Facility (http://www.niboch.nsc.ru/doku.php/corefacility). Nucleotide and amino acid sequences alignments were performed using AliView v. 1.18.1 [6]. Phylogenetic analysis of sequences was performed with the IQ-TREE 1.6.11 program [7].

WHEAT AND AEGILOPS ACCESSIONS USED IN THE STUDY AND THEIR PHENOTYPES

\begin{tabular}{|c|c|c|}
\hline Species & Accession & Phenotype \\
\hline Triticum monococcum L. & PI 289599 & Non-brittle rachis \\
\hline T. urartu Thum. ex Gandil. & IG-44829 & Brittle rachis \\
\hline T. boeoticum Boiss. & К-40118 & Brittle rachis \\
\hline $\begin{array}{l}\text { T. dicoccoides (Körn. ex } \\
\text { Asch. \& Graebn.) Schweinf. }\end{array}$ & PI 467027 & Brittle rachis \\
\hline $\begin{array}{l}\text { T. dicoccoides (Körn. ex } \\
\text { Asch. \& Graebn.) Schweinf. }\end{array}$ & PI 66841 & Brittle rachis \\
\hline $\begin{array}{l}\text { T. dicoccum (Schrank) } \\
\text { Schuebl. }\end{array}$ & к-7500 & Brittle rachis \\
\hline $\begin{array}{l}\text { T. dicoccum (Schrank) } \\
\text { Schuebl. }\end{array}$ & к-327430 & Brittle rachis \\
\hline T. karamyschevii Nevski & KU190 & Brittle rachis \\
\hline T. turgidum L. & к-16156 & Non-brittle rachis \\
\hline T. durum Desf. & к-17784 & Non-brittle rachis \\
\hline T. durum Desf. & к-17787 & Non-brittle rachis \\
\hline T. turanicum Jakubz. & к-15993 & Non-brittle rachis \\
\hline T. polonicum L. & к-39297 & Non-brittle rachis \\
\hline T. polonicum L. & к-17893 & Non-brittle rachis \\
\hline T. aethiopicum Jakubz. & 18999 & Non-brittle rachis \\
\hline T. carthlicum Nevski & к-7106 & Non-brittle rachis \\
\hline T. araraticum Jakubz. & к-30258 & Brittle rachis \\
\hline T. araraticum Jakubz. & к-31628 & Brittle rachis \\
\hline T. timopheevii (Zhuk.) Zhuk. & к-29537 & Brittle rachis \\
\hline T. timopheevii (Zhuk.) Zhuk. & к-29540 & Brittle rachis \\
\hline Aegilops speltoides Tausch & Ae-352 & Brittle rachis \\
\hline Ae. speltoides Tausch & к-1596 & Brittle rachis \\
\hline
\end{tabular}


Results

We obtained the Btrl (Btrl-A and Btrl-B) and Btr1-S sequences for 14 wheat species and $A e$. speltoides, respectively (Table I).

For diploid wheat accessions the length of the Btrl-A sequences obtained were $902 \mathrm{bp}$. In the case of tetraploid wheat accessions, the length of the gene sequences was 899 bp. There were $1 \mathrm{bp}$ deletion in the upstream and $2 \mathrm{bp}$ deletion in the coding region of the Btrl-A gene compared with diploids. According to the comparative analyzes, the $B \operatorname{trl} 1-A$ gene sequences of T. monococcum (PI 289599), T. urartu (IG44829) and $T$. boeoticum (k-40118) were identical with sequences presented previously [2]. Deletion of $2 \mathrm{bp}$ in the Btrl-A coding region of 11 tetraploid wheat species studied was identical to hexaploid wheats $[3,5]$. This deletion formed a premature stop codon and resulted in a non-functional protein [3].

Nucleotide sequences of Btrl-B and Btrl-S genes were detected for the first time. For all tetraploid and Aegilops accessions analyzed the length of the Btrl-B and Btrl-S sequences were variable. This varialibility was caused by poly-(GA) track in promoter region of the genes. No indels in coding region were detected.

We conducted phylogenetic analysis of Btrl genes from di- and tetraploid wheat species and Ae. speltoides. The data obtained allowed us to clarify the phylogenetic relationships between Triticum and Aegilops genera.

\section{Acknowledgment}

The study was supported by the Russian Science Foundation (grant №: 16-16-10021).

\section{References}

[1] Pourkheirandish M., Hensel G., Kilian B., Senthil N., Chen G., Sameri M., Azhaguvel P., Sakuma S., Dhanagond S., Sharma R., Mascher M., Himmelbach A., Gottwald S., Nair S.K., Tagiri A., Yukuhiro F., Nagamura Y., Kanamori H., Matsumoto T., Willcox G., Middleton C.P., Wicker T., Walther A., Waugh R., Fincher G.B., Stein N., Kumlehn J., Sato K., Komatsuda T. (2015) Evolution of the Grain Dispersal System in Barley. Cell. 162(3):527-539.

[2] Pourkheirandish M., Dai F., Sakuma S., Kanamori H., Distelfeld A., Willcox G., Kawahara T., Matsumoto T., Kilian B., Komatsuda T. (2018) On the origin of the non-brittle rachis trait of domesticated einkorn wheat. Front Plant Sci. 8:1-10.

[3] Zhao Y., Xie P., Guan P., Wang Y., Li Y., Yu K., Xin M., Hu Z., Yao Y., Ni Z., Sun Q., Xie C., Peng H. (2019) Btrl-A induces grain shattering and affects spike morphology and yield-related traits in wheat. Plant Cell Physiol. 60:1342-1353.

[4] Vavilova V., Konopatskaia I., Blinov A., Goncharov N.P. (2020) Evolution of Btrl-A gene in diploid wheat species of genus Triticum L. Russian Journal of Genetics. 56 (5): 1-6 (in Russian).

[5] Vavilova V., Konopatskaia I., Goncharov N.P. (2019) Non-brittle rachis 1-A (Btrl-A) gene in di- and hexaploid wheat species. Current Challenges in Plant Genetics, Genomics, Bioinformatics, and Biotechnology. 202-204.

[6] Larsson A. (2014) AliView: a fast and lightweight alignment viewer and editor for large data sets. Bioinformatics 30(22): 3276-3278.

[7] Nguyen L.T., Schmidt H.A., von Haeseler A., Minh B.Q. (2015) IQTREE: a fast and effective stochastic algorithm for estimating maximum-likelihood phylogenies. Mol Biol Evol. 32(1): 268-274. 